\title{
"Inherited Gentrification": Changing Profiles of Gentrifiers via Inheritance, The Case of Bozcaada
}

\author{
Duygu Okumuş1๑ \\ ${ }^{1}$ Lecturer, Faculty of Architecture and Design, Bursa Technical University, Bursa, Turkey. Email: duygu.okumus@btu.edu.tr
}

\begin{abstract} Purpose

Rural areas have been through structural changes. The reorganisation of the rural economy from agriculture to services, in addition to improvements in transportation and infrastructures, migration patterns have started to reverse in some regions and hence to change the social composition of those regions' rural areas. These changes and their implications have been largely debated in the rural gentrification literature, mainly by re-presenting cases from the Anglo-Saxon world. This paper contributes to the rural gentrification literature by presenting an empirical study on a socio-cultural and demographic change that, together with a local economic shift, is taking place in a location other than the Global North.

Design/Methodology/Approach

A qualitative case study examining the changes on the socio-spatial structure of a small Turkish island, Bozcaada, is presented through the following principal indicators of countryside gentrification: the change in the socio-economic composition of its citizens; the emphasis on cultural or national heritage and aesthetics; the emergence of new institutions leading to the closure of older ones; the diversification of products and services; and the change in properties' value.

\section{Findings}

The first-generation newcomers were in line with the typical gentrifier's profile of rural gentrification studies. Differently, the second-generation newcomers have shown diversity in terms of both motivation and socio-economic class. This study argues that the second-generation newcomers took part naturally in the gentrification process not because they inherited their parents' properties, but also they play an important role in the significant socio-economic and cultural changes that are still taking place on the island.

\section{Research Limitations/Implications}

The fact that the research is based on a single case study is a limitation for its generalisation. However, the case examined provides a basis for future work that may validate its findings in different contexts.

Originality/Value

This paper contributes to the rural gentrification literature by introducing a new type of gentrification process, the 'inherited gentrification' with the identification of the second-generation gentrifiers of the island, who are the direct descendants of the first gentrifiers.
\end{abstract}

Keywords: Gentrification, tourism development, rural transformation, gentrifiers 


\section{INTRODUCTION}

Rural areas have been through structural changes which were reflected in the economy, social structure and demography, and the composition of the community and rural land. These structural changes in Turkey had commenced in 1980s. In early years of 1980s Turkey embraced neo-liberal economic policies. This initiated a series of significant transformations in its agricultural economy (Aydın, 2002) mostly felt by small-scale farmers (Köymen \& Öztürkcan, 1999). These transformations of the rural economy were intensified in the early 2000 s and resulted in the rapid de-ruralisation of the population in most regions of Turkey, as small-scale farmers became unable to sustain their livelihood through agricultural production (Keyder \& Yenal, 2011). The local population in the countryside sought new income sources other than agriculture: many started to commute to city centres or industrial zones in their vicinity, while other left their villages and migrated to cities (Tekeli, 2008). The local communities of rural areas, especially those in coastal regions with distinctive historical, cultural, and natural qualities, such as the Aegean and the Mediterranean, took the opportunity to diversify into the tourism sector. In addition to the shift in local economy, substantial changes started to occur in the local social structure and in the landscape, as commonly observed in rural gentrification studies (Başaran Uysal \& Sakarya, 2018; Hall, 2006; Phillips, 2009; Phillips \& Smith, 2018). The rural areas mainly located along the coast and in close proximity to big cities have already been used for secondary housing and recreation purposes for a long time (Akgün et al., 2011). One of those areas is Bozcaada, a small island in the North of the Aegean Sea that has experienced a change from viniculture to tourism (Okumus, 2018).

This paper follows from a research investigating the socio-economic and cultural transitions in Bozcaada that stemmed from this change, and focuses on the change in the social fabric of the island by examining, through qualitative research, the changes in the demographics, in the socio-cultural environment and on the built environment taking place on the island. The data consist of semi-structured and in-depth interviews with island's residents and representatives of local and regional governmental bodies.

This paper contributes to the rural gentrification literature by introducing the concept of 'inherited gentrification', discussed from a generational perspective. The concept of inherited gentrification represents the transfer of the gentrification phenomenon to a new generation via inheritance. Nonetheless, it does not refer to a simple transfer of ownership of gentrified assets and a reproduction of the process of gentrification by the next generation. It refers to an ongoing and constantly changing process of transformation that, alongside the socio-economic and cultural changes, occurs on the island and in the wider society. 
"Inherited Gentrification": Changing Profiles of Gentrifiers Via Inheritance, The Case of Bozcaada

\section{DIFFERENT APPROACHES TO GENTRIFICATION}

There are two main schools of thought that explain the causes of gentrification: the productivist/supply-side and the postproductivist/consumption-side approaches. The productivist/supplyside approach is centred upon the economic structures of gentrification and claims that the notion of gentrification should be investigated through the productive investment of capital, which relates to the "rentgap" theory of Smith (1979).

Although the production-side approach to gentrification theories has been widely explored in the urban context, it has been relatively little used in rural studies. Phillips (1993) drew an analogy between postproductivism and rural gentrification theories. The notion of the postproductivist countryside in rural studies relates to the devalorisation of land and buildings with respect to agricultural production and its uneven revalorisation with respect to more consumption-oriented capital networks. Therefore, rural gentrification can be seen as "one form of the revalorisation of resources and spaces which have become seen as unproductive or marginal to agrarian capital"(Phillips, 2005, p.479). Conversions of barns and other rural buildings into residential, retail or leisure facilities are the most visible example of postproductivist approach to rural gentrification and of the process of devaluation and revaluation.

Darling (2005) suggested that the cycle of devaluation and revaluation is also applicable to national parks, which have a bespoke set of legislative restrictions; she named this unique case of gentrification "wilderness gentrification". She suggested that the wilderness character of the area led to a devaluation of the region due to the special landownership patterns and conservative regulations of the state. This "peculiar condition" of the Adirondack State Park has conditioned an "underutilisation of ground rent" and underpinned the preservation of the landscape, which became very desirable to tourists and subsequently stimulated capital investment in the area (Darling, 2005). Productivist/supply-side and post-productivist approaches to gentrification are criticised for lacking a historical and cultural approach (Zukin, 1990). In contrast, consumption/demand-side approaches emphasise the movement of people rather than capitals. Consumption approaches also aim to identify the typology and motivation of gentrifiers and are usually based on empirical, place-based research. Consumption-side approach research therefore focuses on sociocultural changes in the countryside, consumer preferences and middleclass concepts of rurality (Butler, 2007; Ley, 1987; Skeggs, 2004; D P Smith \& Phillips, 2001).

Studies adopting consumption-side approaches have been predominantly covered under various titles such as counterurbanisation, rural in-migration, rural population change, rural mobility and so on, exploring social changes in the countryside rather than rural gentrification. However, Stockdale (2010) claims that those 
studies failed to make explicit conceptual linkages, which the concept of rural gentrification did, and summarises rural gentrification as "counterurbanisation which leads to displacement".

Glass's (1964) conceptualisation of gentrification highlighting middleclass in-migration and working-class displacement has been applied to several rural studies, especially British ones. In the rural context, middle-class ex-urbanites migrate to rural areas and displace workingclass locals and their rural way of life by outbidding them in the housing market, dominating local and social organisations as well as the market sector (Cloke et al., 1995; Guimond \& Simard, 2010; Phillips, 1993, 2002, 2005; Scott et al., 2011; Shucksmith, 2012; Sutherland, 2012). However, debates over the definition of "middle-class" have a critical importance when defining gentrifiers in gentrification studies. Although income is the primary parameter in use to describe the socio-economic and sociocultural structure of a particular population, it is very important to support it with other parameters such as employment, education level and occupation, as a person can be poor in economic capital but rich in cultural capital, which makes them a 'good' gentrifier (Stockdale, 2010). In addition to problematic definitions of the contemporary middle classes and working classes, Hamnett (2009) also criticises class colonisation and displacement perspectives of rural gentrification for disregarding the general decline of the working class and increasing the volumes and sub-fractions of the middle class at a national level. $\mathrm{He}$ stated that: "If we are to see gentrification as a class-based process, it is important to address the questions of where the expanded middle-class has gone, and what the connections are between gentrification, social class change and displacement" (Hamnett, 2009, p.476).

Gentrification is widely accepted as a process which is diverse and varies in its outcomes. However, Davidson and Lees (2005) give some "evidence[s] of change" that are linked to each other: reinvestment of capital, social upgrading of the locale, landscape change, and displacement of low-income groups. Reinvestment of capital through purchase and refurbishment of existing housing stock leads to changes in the landscape, while social upgrading of the locale through migration of the middle class leads to displacement of low-income groups. Even though this conceptualisation breaks down the concept of gentrification into four main "changes", it does not necessarily imply an order amongst them.

\section{Gentrification in The Countryside}

This complex urban phenomenon of gentrification emerges in the countryside with similar principal indicators (Guimond \& Simard, 2010): a change in the socio-economic composition of its citizens; an emphasis on cultural or national heritage and aesthetics; the emergence of new institutions leading to the closure of older ones; the diversification of products and services; and the change in properties' value. 
"Inherited Gentrification": Changing Profiles of Gentrifiers Via Inheritance, The Case of Bozcaada

Guimond and Simard (2010) claim that, unlike its urban counterpart, rural gentrification does not necessarily lead to the displacement of locals and lower-income groups due to the possibility of new build development in rural places. However, Murdoch and Marsden (1994) state that once higher income groups move into rural settlements, they resist to any further development in the area, which subsequently leads to an increase in housing prices and the inevitable displacement of lower-income groups.

According to Phillips (1993), there are two principal problems with applying urban phenomena to the countryside. Both the transformation of the built environment and the characteristics and motivations of gentrifiers take place differently in each context. Although there is "evidence of change", as Guimond and Simard (2010) suggested, "rural areas themselves may be sufficiently differentiated to render the idea of an overarching, homogeneous 'rural gentrification' suspect" (Darling, 2005, p.1015). Thus, it is inevitable that there will be geographical differences produced by different agents (Phillips, 2005; Scott et al., 2011). It is a "multi-faceted process" (Stockdale, 2010) that evolves through different stages and subsequently generates different outcomes, according to geography, time and agents.

Since rural gentrification has been defined through a socio-cultural change in the countryside, especially by consumption-side theories, it has been discussed under a diverse range of topics related to the influx of population towards rural areas. Counterurbanisation as a "migration movement" (Mitchell, 2004) is the most popular concept that correlates with the rural gentrification concept. For example, Sutherland (2012) described rural gentrification as a counterurbanisation with displacement of the low-income groups by adding the social-class dimension into the migration debate. Therefore, counterurbanisation studies take a significant space in the rural gentrification literature.

As in rural gentrification, defining such a complex "socio-spatial structure" runs the risk of narrowing and limiting diversity (Halfacree, 2001; Mitchell, 2004). By avoiding the conceptualization of counterurbanisation, Gkartzios (2013) presents three "interrelated

1 Gkartzios uses "counterurbanization stories" instead of typologies in order to emphasise the unique patterns of each case. elements of differentiation" in counterurbanisation "stories": ${ }^{1}$ locality, motivation, and social group. These elements can also be used in the context of rural gentrification.

\section{Land-use Planning, Housing Policies and Gentrification}

Rural gentrification from a planning perspective has been mostly examined through issues of housing supply, housing affordability, and the subsequent displacement of locals. Planning regulations that restrict the supply of new housing and further development in the countryside can act as a "gentrification agent" (Gkartzios \& Scott, 2012; Scott et al., 2011). For example, in the UK, the dual pressure of a restrictive housing supply and the effect of rural in-migration has resulted in an acute affordability issue for local communities, which eventually leads to the 
issue of displacement (Best \& Shucksmith, 2006; Gallent \& TewdwrJones, 2007; Shucksmith, 2012; Stockdale et al., 2000). Gkartzios and Scott (2012), however, showed that in countries where rural planning regulations (if they exist) or house-building processes in the countryside are more flexible, rural in-migration/counterurbanisation is less likely to generate the displacement of locals.

On the other side, Cloke (1983) claims that pressured rural areas with restrictive policies attract the gentrification process and prevent the building of dwellings for local needs. In her study in the Adirondack region, USA, Darling (2005) stated that the material production of nature, such as the national park and preservation areas, by the state management of local landscape, creates the conditions for gentrification to take place. Moreover, as it promotes more interest towards the area through alternative tourist activities, it underpins not only the displacement of locals but also the exclusion of newcomers who came to the area with employment-led motivations, due to the increased number of second homes and holiday homes where housing stock was already limited. For example, in the Webb area of Adirondack, the shortage of year-round rentals due to the high demand for weekly rentals has forced workers to double or triple up with other workers to avoid long commuting journeys every day (Darling, 2005).

\section{Gentrification from within}

Sutherland (2012) has described the gentrification process in noncommercial farming in the UK, arguing that "while gentrification can occur 'without' through in-migration and displacement of existing farmers, it can also come from 'within' through reorientation of commercial farmers"(p.574), and introduced the concept of "gentrification from within", referring to "social upgrading" through "agricultural gentrification" that occurs at farm (rather than neighbourhood) level, achieved through the influx of wealth generated from non-farming activity. Having agricultural land as a productive resource alongside housing and other farm building is the major feature of agricultural gentrification that makes it possible for farmers to "selfgentrify", increasing their social status without relocation. In her research on the Scottish countryside, Stockdale (2010) also identified the particular importance of diversified farmers, especially those with commercial activities that drew on rural resources. This selfemployment through diversification in the countryside is related to the "production of rurality", particularly through tourism or retailing.

\section{Gentrification Studies in Turkey}

Turkey has started to experience gentrification processes later than the global north, roughly in the 80's and the gentrification literature in Turkish context started to be published in the 2000's. Majority of the gentrification studies in Turkey examine the phenomenon through urban cases in major metropolitan areas such as İstanbul and Ankara 
"Inherited Gentrification": Changing Profiles of Gentrifiers Via Inheritance, The Case of Bozcaada

(Behar \& İslam, 2006; Enlil, 2000; Ergun, 2004; Güzey, 2009; İslam, 2005; Şen, 2011; Uzun, 2003). Rural gentrification studies, however, has just started to be debated in Turkey. Currently available studies (Başaran Uysal \& Sakarya, 2018; Dinçer \& Dinçer, 2005; İslam, 2005; Kural, 2016) focus on the coastal part of Aegean countryside mainly dominated by tourism investments and second houses since 1980's. As in Western counterparts, disinvestment-reinvestment cycle, change in social structure and rural landscape, and the process of displacement are also represented by empirical rural gentrification studies in Turkish context (Başaran Uysal \& Sakarya, 2018; Kural, 2016; Tezcan, 2010).

\section{METHODOLOGY}

This paper follows from a research which explored the socio-economic and cultural transitions on Bozcaada through a qualitative study. Bozcaada is one of the two island districts of the province of Çanakkale, the other being Gökçeada. Although these two islands present quite a similar cultural-historical background, during the last three decades they have shown rather different development processes. Bozcaada, being more accessible from the mainland, has attracted more visitors and, in the late 1990s and early 2000s, diversified into tourism, which led to a demographic change in the social fabric (Okumus, 2018). Differently, Gökçeda has not yet experienced a substantial change in the local economic and social structure. Bozcaada was therefore chosen for this study to examine the socio-economic and cultural transitions within the context of rural gentrification.

A set of primary and secondary data collection methods based on qualitative research was followed throughout the research. Primary data was collected by undertaking two-phase fieldwork, while secondary data, including demographic and economic statistics, archive review, and review of local news, was collected continuously over the research period between 2014 and 2017.

The fieldwork on the case study area was planned to be conducted in two phases of primary data collection, one during the peak tourism season (March-April 2016) and one during the off-season (May-June 2015) with the objective of capturing seasonal differences. During the fieldwork, a total of 39 in-depth and semi-structured interviews were conducted with local residents and representatives of local and regional governmental bodies. Four different groups of residents were identified for the interviews, based on their residential status on the island. For example, "ISD" stands for the islanders who had lived on the island for many generations, "LX" stands for the locals who moved to the island

2 The members of this group is referred as "localXs" throughout this research to distinguish them. after the departure of the Rums ${ }^{2}$ and "NC1" and "NC2" stand for the newcomers who moved to the island in the last two decades.

\section{THE CASE OF BOZCAADA}

Bozcaada is a small Turkish island located in the north of the Aegean Sea, four miles away from mainland Turkey and connected to it via a 
regular ferry service. This small island presents excellent examples of socio-economic and cultural changes that are seen in contemporary rural areas. The island's local economy was based on viniculture for centuries until the last couple of decades. During the last decade, Bozcaada became one of the most prominent domestic tourist destinations for the residents of Turkey. Although viniculture is still one of the characteristics of the island, it is only carried out by a number of boutique local wineries on the island. The local economy of the island is now predominantly based on tourism. Almost every household on the island is directly or indirectly involved in tourism.

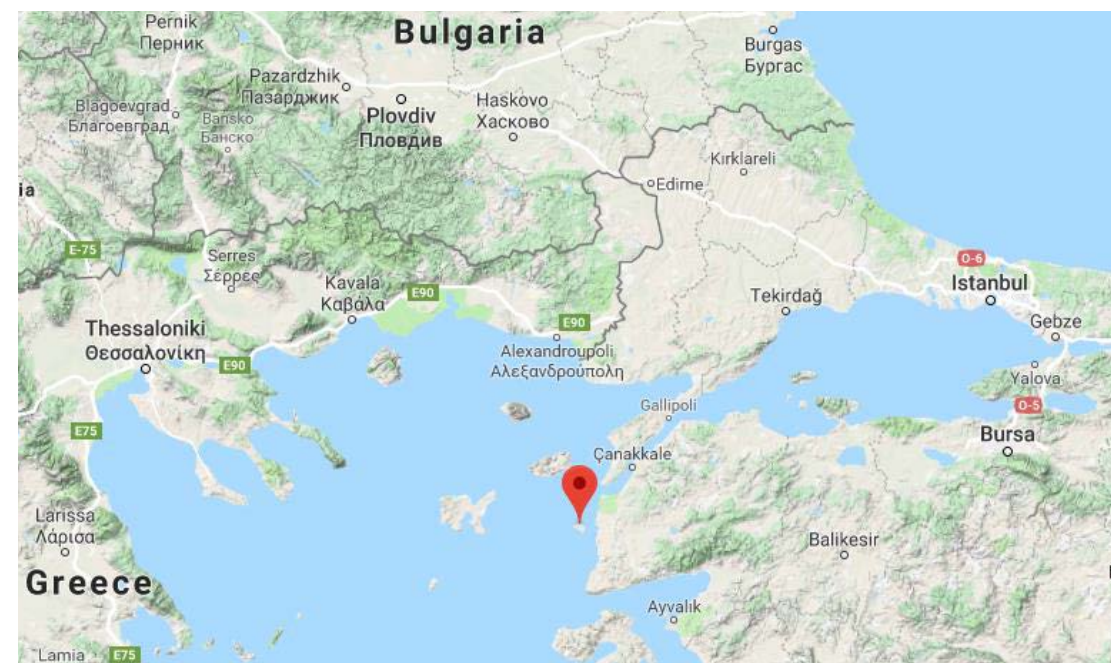

\section{Demographics}

As Figure 2 shows that the gradual decrease of Bozcaada's population due to the departure of the Rums ended in the 1980s, and turned into a steady increase with minor fluctuations between 2000 and 2010. The increase after the 1980s corresponds to the arrival of agricultural workers from the surrounding areas on the mainland, who used to work in grape harvesting and the winemaking industry, as a result of the gap in the local community and the local economy created by the departure of the Rums.

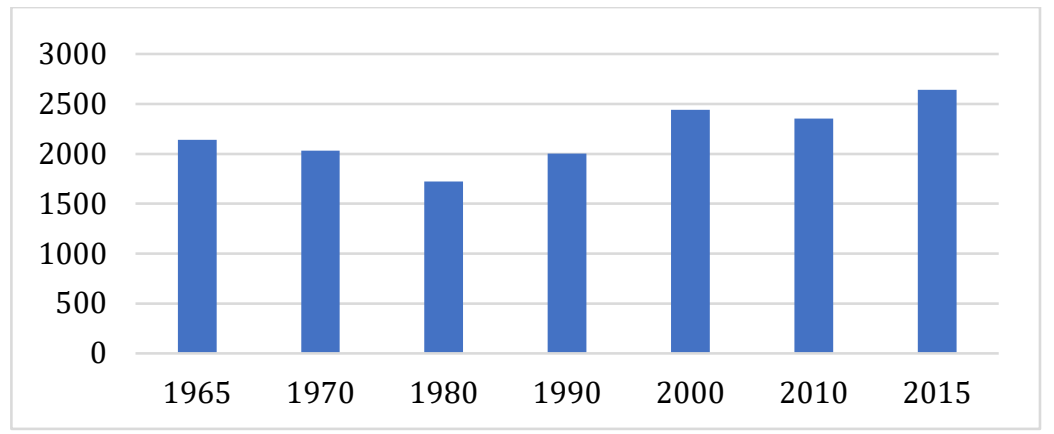

The small fluctuation in the population of Bozcaada between 2000 and 2010 coincides with the period in which tourism was becoming the main economic activity on Bozcaada. As stated during the interviews
Figure 1. Location map of Bozcaada (Google Maps, n.d.) The island located in the north of the Aegean Sea, four miles away from the mainland

Figure 2: Population change on Bozcaada since 1965. A gradual decrease of Bozcaada's population due to the departure of the Rums ended in the 1980s. 
"Inherited Gentrification": Changing Profiles of Gentrifiers Via Inheritance, The Case of Bozcaada

with the local residents, there were families who were keen to move from the island but not able to afford to do so. Local tourism development and the increasing popularity of the island in these years helped those families to sell their property for higher prices than they expected and finance their out-migration. Since the properties that sold in this period were mainly used as holiday/second homes, we see a small decrease in the registered population on Bozcaada. After this early period of tourism on the island, the trend of population increase on Bozcaada continued.

\section{In-migration}

One of the most commonly used indications of gentrification and counterurbanisation movements is the migration pattern. However, to be able to make a more accurate critique of migration patterns on Bozcaada, detailed migration statistics showing the origins of the migrants in certain time periods are needed. Unfortunately, this data is only available at regional and provincial level. Nevertheless, Table 1 shows the proportional population change on Bozcaada between 1990 and 2014 according to the birthplace of the residents. This proves that the proportion of the local population who were born on the island has been decreasing since 1990. It is important to note that, in Table 1, "Canakkale" includes the population who were born either on Bozcaada or anywhere within the borders of Canakkale province, including the population who moved to the island from the surrounding rural areas after the departure of the Rums.

Table 1. Distribution of Bozcaada's population according to birthplace (adapted from TUIK, 2015)

\begin{tabular}{|l|l|l|l|l|}
\hline Birthplace (\%) & $\mathbf{1 9 9 0}$ & $\mathbf{2 0 0 0}$ & $\mathbf{2 0 1 0}$ & $\mathbf{2 0 1 4}$ \\
\hline Canakkale & 69 & 61 & 66 & 58 \\
\hline Istanbul & 3 & 7 & 8 & 11 \\
\hline Balikesir & 2 & 3 & 3 & 3 \\
\hline Bursa & 1 & 1 & 1 & 2 \\
\hline Abroad & 1 & 2 & 2 & 2 \\
\hline Total population & 1903 & 2427 & 2324 & 2773 \\
\hline
\end{tabular}

3 Taking into account Turkey's internal migration patterns, Bozcaada has a community with a population that was born in over 60 different provinces, as do many towns. For the sake of readability, only those provinces that are the birthplaces of more than $2 \%$ of the population in 2014 are shown in Table 1.
The notable point of Table 1 is that it shows possible counterurbanisation movements on Bozcaada. Table 1 only shows those provinces that are the birthplaces of at least $2 \%$ of the current population on the island. ${ }^{3}$ The three cities of Bursa, Balikesir and Istanbul are the closest metropolitan cities to Bozcaada. The proportion of Bozcaada residents who were born in metropolitan areas has been increasing gradually every decade. Nevertheless, this figure may not clearly show the increase of in-migrants in the local population, as it also shows a steady increase of the population who were born in Canakkale province. The percentage of local residents who were born in Istanbul has increased from $3 \%$ to $11 \%$ since 1990 . However, during the 
same period, the number of residents born in Canakkale dropped from $69 \%$ in 1990 to $58 \%$ in 2014. This represents a clear indication of a gradual increase of Istanbulians on Bozcaada; however, it should be recognised that this deduction is based on the data, which cannot give an absolute portrayal of the local community on Bozcaada. Therefore, the interviews and observations undertaken during the fieldwork were of great importance in identifying the social component of the current local community.

\section{Newcomers}

In rural gentrification literature, active agents of gentrification are usually middle-class or upper-class ex-urbanite newcomers who are usually in search of "a retreat from the pressures of the modern world"(Smith \& Phillips, 2001, p.464). On Bozcaada, the profiles of the newcomers correspond to this mainstream profile of rural gentrifiers in terms of being ex-urbanites escaping from the distressing "big city life". However, not all the newcomers are from the relatively wealthier upper or middle classes. Some of the newcomers are young families who cannot afford a property with their savings yet, but they inherited or took over their parents' properties, which were once in use as summer houses. One of these second-generation newcomers turned their properties into $\mathrm{B} \& \mathrm{~B}$ accommodation and started running it themselves while trying to continue their jobs in part-time positions:

"He [the husband] teaches at the university. It was very appropriate for us as he is pretty much free in summer and we have got a little child; we always wanted her to grow up in such a natural environment. We are free in summer and already have a property here from his parents, so why not put it into good use ... We were able to come here as we already have a property [from his parents]. Otherwise it would be impossible as we don't have such money to buy a property here." (NC2-A)

"We settled permanently here last year. I studied advertising at university, my wife as well. We were working in different companies as advertising managers. However, we decided that we don't want to work in constant pressure in this economic system. And also, Istanbul has its own problems like traffic jams, population increases, earthquake risks etc. ... Therefore, we wanted to escape from Istanbul, but didn't think of Bozcaada at first. Then we thought that we already had a house which we used as a summer house for years, let's go to Bozcaada and try and see what we can do there. So we came here and have been living here for a year." (NC2-D)

Since the newcomers tended to be regular visitors to the island before moving in, they are usually familiar with the local social environment. 
"Inherited Gentrification": Changing Profiles of Gentrifiers Via Inheritance, The Case of Bozcaada

Therefore, integration into the local community may not be an issue. During the fieldwork, none of the interviewees explicitly reported any challenges to integration with the rest of the community. Although two interviewees below explained that their integration period with the community was smooth, they also emphasised that there is a "superiorsubordinate relation" based on the length of time lived on the island, as in the military ranking system.

"There is no owner of the island, no indigenousness here if you look back [in history]. Being an islander is something everybody here can earn. But there is also this 'you came later, hold on' ... like in the military." (NC2-C)

"Usually the first wave (of newcomers) does not like the second wave, just like older generations do not like younger generations. It is in human nature." (NC1-A)

Apart from the integration of newcomers, in-migration of more affluent groups is generally viewed as a threat to local communities, due to the fact that in many cases it results in the displacement of local community members. However, a change in the local social fabric, usually through in-migration of more affluent and well-educated groups, may also have positive outcomes. One of the main "benefits" is the catalysis effect of newcomers on the development of local tourism on Bozcaada (Okumus, 2018). Besides, based on the interviews undertaken on Bozcaada, the newcomers brought "quality" and "awareness" to the everyday practices of the local community. The interviewees below explained their opinions of how the newcomers helped with local tourism and the social development of the island.

"Sometimes they [the newcomers] love and watch out for the island more than us. Because they can see what we don't see. For example, I was born and bred here, never got off the island. But they come well-educated, they help us a lot." (ISL-A)

"Before the Istanbulians came, the situation in the schools was not very good. Because parents were not getting involved. They were even hardly going to parent-teacher meetings. Then young families came here with children. They sent their children to the local school and got involved in the school board etc. so the quality has increased since then." (NC1-E)

"Some people [from the newcomers] give free classes for children here. Some give photography, another gives English, another gives ceramic courses." (ISL-E)

In addition to free classes for the local children, the newcomers initiated something else that happened to be a very important contribution to the local socio-cultural life: the local online newspaper "www.bozcaadahaber.net" and the local monthly journal Mendirek. The online newspaper was founded in 2014 with the assistance of two 
newcomers who worked as journalists and provides daily news about the island. The same group started to publish a local journal with the motivation of creating an archive of the island. However, both of them are currently prepared by an editorial board that includes members from the three social groups of the local community: the newcomers, the localXs and the islanders. The online newspaper and the journal also work as important tools to make connections with the outside world as well as creating a platform for discussion and participation on the island.

\section{Housing market}

The most visible change in the island's built environment during the last two decades was inevitably the housing market, with ever-increasing prices for any kind of property. Increased demand for property on the island brought extreme benefit for the landowners of Bozcaada, but also seriously affected the younger generations of the local community and the civil servants who were appointed to the island.

\section{Rising property prices}

It is a basic principle that if the housing supply cannot meet the housing demand, property prices will increase. This is what has been happening on Bozcaada in the last two decades. Bozcaada has become more and more popular since the late 1990 s as a tourist destination and a "getaway" for urbanites. This increasing popularity inevitably caused an increase in demand and in the price of properties on the island. According to online searches and field observations in 2015, the average property was on sale for approximately $£ 1,860(6,661 \mathrm{TL})$ per square metre on Bozcaada. This figure is almost double the average price of $£ 946$ per square metre in Istanbul, which is the most expensive city in the country and holds second place in the world for the highest increase in property prices in 2015 (Satterlee, 2015).

Inevitably, there are many reasons for rising property prices, such as the increase in demand as well as the shortage of supply in the local housing stock on Bozcaada. Being a tourist destination played the biggest role in the increase in housing demand. However, being subject to strict conservation regulations also limits the number of possible actions to meet the demand within the existing built environment, and consequently causes the price increases. A real estate agent interviewed on Bozcaada gave an example of this ever-increasing value in the local property market and how "everybody wins" since the 1990s in the local real estate market on Bozcaada.

“... there was a piece of land at that time [the early 1990s], since then it has changed hands seven times and the price increased at every sale; each seller made a profit out of it." (local real estate agent)

These highly inflated property prices have both negative and positive outcomes for the local community. On the one hand, they provide 
"Inherited Gentrification": Changing Profiles of Gentrifiers Via Inheritance, The Case of Bozcaada

enormous financial support for the residents who own a property to rent out, since rents also increase. On the other hand, members of the community who do not own a property struggle to find accommodation. Even if the price were not an issue, finding an available place may be a challenge due to second homes and short-term holiday rentals on the island.

Second homes and short-term rentals

During the high season of local tourism, which covers around three months of the summer, the population of the island goes up to 10,000 on average. Given that the total number of beds on the island is 3000 and the local population is around 2500 , the remaining 4500 people, more than half of the summer population, are holidaymakers who do not stay in formal hotels or guesthouses but in short-term rentals or their own holiday houses. For example, on the AirBnB website, there were 74 properties being advertised for short rentals on Bozcaada as of November 2016. Although it should be noted that some of those advertisements are people who rent out their spare rooms, short-term rentals seem to be the most visible cause of the lack of affordable housing on the island. This issue was even raised by the mayor during the interview.

"There is a serious housing problem. Also, there is big demand. So even though you found a house, its rent is very high. Because people make very serious income through tourism in summer, they do not want to rent out their houses in winter. They make the same money in ten days that they can make if they rent out the house all year round." (Mayor)

The mayor mentioned that the local community rent out their spare properties in summer. However, another point made by another interviewee focused on the second home owners who have bought a property on the island to use occasionally. Due to the fact that property prices on the island are very inflated, only the wealthy can afford to buy a house to use for a limited time and keep it locked up for the rest of the year. The interviewee suggested that these houses, which are unused for the majority of the year, contributed to the shortage of housing on Bozcaada.

"If somebody pays 500K TL for a house to use only a month in a year, it means that that person does not need money. So he [or she] does not give his [or her] house to another person to rent. He [or she] comes and stay a month here and keeps it locked up for 11 months." (ISL-D)

Lack of affordable housing

As the housing demand on Bozcaada exceeds the supply, the prices and rents of the existing houses increase enormously. This situation has an 
immense effect, particularly on the people who come to the island to work. The civil servants who are appointed to work on the island, such as doctors and teachers, have difficulty in finding affordable places to live all year round. As mentioned earlier in the mayor's quotation, the local homeowners prefer to rent out their houses in summer for a short period. Therefore, they either keep them vacant for the rest of the year, or rent them out from October to May only. Two interviewees who are teachers in the local school shared their experiences of finding accommodation when they first moved to the island:

"They said that, If you stay all the year round you [will] hamper our tourism income,' so they asked me to evacuate the house before May. Because they rent the house as a pension in summer." (OFF-B)

"... if you wanted to stay for the whole year, they were asking for 1000 TL at that time [nine years previously]. My salary was around $1800 \mathrm{TL}$ at that time, so I had to pay the rent with more than half of my salary." (OFF-C)

There are 48 lodgement houses on the island in total. Twenty of them are reserved for the local municipality and another 20 are reserved for governorship officials. The remaining eight lodgement housing units are allocated for the civil servants in education and health. However, this number is lower than what is needed. Some of the single civil servants had to share their flats with others. In particular, new arrivals are the ones who suffer the most from the lack of affordable housing, which subsequently pushes them to ask to be appointed elsewhere. This situation has also effects on maintaining good public services on the island.

"Rents are so high. Civil servants who have been appointed here do not want to stay here, because there is not enough lodgement for everyone. A teacher who is paid between 2000 and 3000 TL has to pay a rent around 1500 TL." (NC2-D)

Lack of affordable housing on Bozcaada is not a problem only for the new residents who recently came to the island for work purposes, but also for the locals who do not own a property on the island. In particular, the young adults of the local community are in the group who are most affected by these high rents and property prices. The younger generations who want to move out from their family house may not be able to do so under these conditions. One of the interviewees below gave an example of his friend's experience as well as his own. Another interviewee was also highly critical of the landowner's behaviour and also the conditions that he has to live in while paying such a high rent:

"Rent here is so expensive. Thankfully we have a house from my grandparents, so we all live there. One of my friends had to wait two years to get married because they couldn't find a house to move into. In the end, they 
"Inherited Gentrification": Changing Profiles of Gentrifiers Via Inheritance, The Case of Bozcaada

got married and continued to live with his parents."

(ISL-G)

"Many people ask for a year's rent in advance. And also, if the roof is leaking etc., they don't repair it. They expect the tenant to pay for it. It is ridiculous! I am living in a $42 \mathrm{~m}^{2}$ flat and paying 1000 TL for that ... but there is no other option." (LX-F)

Another issue that was raised during the interviews was the accommodation problem for seasonal tourism labourers due to the lack of affordable housing on the island. As the number of tourists on the island rapidly increases during summer, the demand for services and labour such as housekeepers, waiters/waitresses and cooks also goes up. Due to the high rents on Bozcaada, the employers struggle to find accommodation for their seasonal employees. Many employers rent a house for a short time and accommodate their employees there in bunk beds. However, the conditions of these houses are not always favoured by the employees, and subsequently affect their performance or are conducive to their early departure. During the interviews, this situation was also raised as an obstacle to providing quality tourism services.

"Accommodation for personnel is problematic. There are 15 people working here only [a restaurant]. But we rent a house for them only. A two-bedroom house for ten people. There is another room behind the restaurant for the family [the cook's family]. Our standards are a bit better than others." (LX-B)

"If you want a certain type of tourist, you need to provide that kind of service. They call for proper chefs and service assistance, but they put them all in one room. Of course, they don't want to work in such conditions. They either ask for more money or leave the next day." (NC2-D)

\section{Conservation}

In 1982, the entire island of Bozcaada was designated as a conservation site for the first time. With this decision, the settlement area of the island was designated as an urban conservation area, the historical monuments and necropolises were designated as archaeological conservation sites, and the rest of the island was protected as a natural conservation site. The fact that Bozcaada as a whole was designated as a conservation area before the development pressure of tourism helped to protect the historical and cultural heritage of the island, which now became the primary component of the island's identity in promoting the local tourism sector. However, this is not always perceived as a positive feature by some interviewees in the local community due to very strict restrictions and complicated regulations to follow, while others believed that the same strict regulations were the "saviour" of the island against the increasing pressure of development. 
Because the traditional layout and architecture of the town centre is under conservation, possibilities for spatial development in the town centre are very limited. One of the interviewees shared how these limitations prevent major investors and entrepreneurs from investing on the island and help to protect it from the development pressure of the tourism sector. Another interviewee emphasised the importance of conservation for tourism by giving an example of another island, Avşa, which is not considered to be a tourist destination any more.

"If you come here and say, 'Find me a 200m² place' [footprint], I will pay whatever you want,' you cannot get anything. There is no such place. So those big businessmen don't come here to invest." (LX-B)

"Avşa was a wonderful island in my university years back in the 1960s, just like Bozcaada before the 2000s. With untouched nature, very quiet beaches and B\&Bs, inexpensive and good wine ... but it has never been declared a conservation site like here. So, they couldn't control the development. All the vineyards were gone, tall buildings by the coast, beaches became polluted as well. Now you wouldn't even hear the name of the island as a tourism destination anymore." (NC1-A)

Although the title of conservation area helped both to protect the heritage and to promote a unique identity for tourism, living in a conservation site comes with its benefits and costs for the local residents of Bozcaada. On the one hand, the value of their properties has gone up more than they would expect due to the rising popularity of the island as a tourism destination, which created such a high demand. On the other hand, renovating their properties or making small repairs costs significant time and money due to the bureaucracy. In conservation sites, any building or modification application must go through several different levels of administrative bodies from the local municipality to the regional conservation council to obtain approval. An interviewee explained how this gruelling process puts some buyers off, as well as leaving the local residents reluctant to renovate their properties:

"They discover older foundations during excavation and think that those are ancient remnants ... of course they stop everything and call the council of monuments and inform them ... then people get dispirited and don't want to buy a house and renovate it." (ISL-E)

Planning and conservation regulations are able to act as a "gentrification agent" by restricting new spatial development (Gkartzios \& Scott, 2012). The limitations on the existing built environment also play the role of the gentrification agent due to the tedious processes of obtaining approval. It was suggested by an interviewee that having to deal with time-consuming and costly bureaucratic works of renovation or rebuilding on Bozcaada allows only the wealthy to buy a property on the 
"Inherited Gentrification": Changing Profiles of Gentrifiers Via Inheritance, The Case of Bozcaada

island. It is possible that this leads to indirect displacement of lowerincome groups by excluding them from the local property market. It also consolidates the change in the socio-cultural structure on Bozcaada.

"Bureaucracy runs so slowly. If you want to take this stone and put it there you need to go to so many different offices and contact so many different people ... So only wealthy people can buy a property here, or people who can access important people and bypass bureaucracy." (ISL-E)

\section{DISCUSSION}

\section{Inherited Gentrification and Second-Generation Gentrifiers}

The finding of this research supported Hamnett's assertion (2003) that gentrification is a process of change which is complex and constantly evolving. The earlier classic pattern of rural gentrification on Bozcaada evolved to be an "other' process of rural gentrification"(Higley, 2008) . This presents itself with the changing typology of newcomers. In the early phase of Bozcaada's gentrification, the newcomers were mainly middle-aged and middle-class urbanites who moved to the island with rural idyll motivations. However, in the current phase, the characteristics of the newcomers have become diversified in terms of both motivations and socio-economic class. First, the second-generation newcomers are not wealthier than the long-term residents of the island due to increased economic status with local tourism development. Secondly, the motivations of second-generation newcomers moving to the island was not only based on lifestyle desires and rural or smalltown idyll, but also on expectations of financial gains, again due to the growing local tourism.

Another point proving that the case of Bozcaada presents an "other' process of rural gentrification" (Higley, 2008)is the integration of newcomers with long-term residents. The second generation of newcomers are more integrated with the different sections of the local community, in contrast to the "classic" rural newcomer typology. The second-generation newcomers are not only integrated with the local community through business connections, but also through strong socio-cultural connections; they show a strong sense of loyalty to the island and the local culture and community.

One of the main aspects of the gentrification concept is its class dimension, since it is often defined in the earlier productivist literature as the displacement of the working classes by the middle classes (Bijker et al., 2012; D P Smith \& Phillips, 2001; Stockdale, 2006). The parameters that are used to define the middle class or portions of it have a critical importance in identifying the potential gentrifiers. Taking income as the sole parameter may not reflect the real picture of today's complex social class structure of populations (Hamnett, 2009; Phillips, 2009; Stockdale, 2010). As Stockdale (2010) suggests, one can be poor in economic capital but rich in cultural capital, which would make one a 
good gentrifier. In addition, an increase or decrease in the size of a particular social class in a given locality may not always manifest an event of displacement, as it may be a reflection of national or global trends in social class change (Hamnett, 2009). For example, the first generation of newcomers on Bozcaada were mainly middle-class, middle-aged ex-urbanites, who closely fitted the typical profile of rural gentrifiers (Cloke et al., 1995; Little, 1987; Urry, 1995). Regarding the later newcomers on Bozcaada, it is harder to determine to which socioeconomic class they belong. This can be explained by the contemporary complex class structure (Phillips, 2009). Besides, the popularity of Bozcaada among domestic tourism destinations and increasing employment opportunities in the service sector certainly had an effect on the change in the newcomers' profile on Bozcaada. This supports Hamnett's (2003) assertion, showing that the gentrification of Bozcaada is still an ongoing process evolving alongside the overall transition of the island.

The most significant finding of this research was the identification of the second-generation gentrifiers of Bozcaada who are the direct descendants of the first gentrifiers. This particular section of current newcomers on Bozcaada are not as wealthy as the other newcomers or their parents. In fact, they may not be able to move into the local community if they have not inherited their parents'/grandparents' properties due to a highly inflated housing market. Although they do not hold economic capital, as Stockdale (2010) suggested they are still part of the gentrifying population of Bozcaada due to their cultural capital, which differentiates them from the other sections of the local community.

Another characteristic of the second-generation newcomers on Bozcaada is that they do not just "consume" the place, as usually described in the literature on rural in-migration and gentrification (Argent et al., 2014; Cloke et al., 1995; Halfacree \& Boyle, 1998; Woods, 2005). On the contrary, they are well-integrated into the local economy, directly contributing to local social and cultural life, and helping to keep services such as schools running. This raises the question of whether the second-generation newcomers can be identified as gentrifiers of Bozcaada.

This paper argues that the second-generation newcomers naturally took part in the process of gentrification when they inherited their properties, since they play an important role in the significant socioeconomic and cultural changes that are still taking place on the island. However, they created a different kind of gentrification from their parents. This paper calls this new concept "inherited gentrification". It may simply be understood as another method of gentrification that is passed down to the next generation via ownership of assets. It is, however, continuously evolving, with the inclusion of new actors in the ongoing process who characteristically differ from the former ones. 
"Inherited Gentrification": Changing Profiles of Gentrifiers Via Inheritance, The Case of Bozcaada

\section{Displacement of Locals or Exclusion of Newcomers}

The rural gentrification literature suggests that due to increased demand for property, rising prices and rents lead to the displacement of a local population (Cloke et al., 1995; Darling, 2005; Davidson \& Lees, 2005; Phillips, 1993; Stockdale, 2006). However, what is seen in the case of Bozcaada can be explained as "exclusion of newcomers" (Darling, 2005) from the property market rather than the displacement of the locals. Tourism on Bozcaada has played a critical role in generating this situation. Firstly, the nature of local tourism on Bozcaada, which started with room rentals in owners' own houses (levels of house ownership are high on Bozcaada), prevented the possible displacement of locals to some extent through their inclusion in the distribution of tourism profits from the beginning.

Secondly, because tourism became highly rewarding for the local landowners, available properties on the island are marketed as short rentals during the tourism high season, and finding affordable yearround rentals becomes almost impossible. Under these circumstances, newcomers who moved to the island with job-led motivations, such as civil servants, are the most excluded group in the local property market. Darling (2005) stated in her study of the Adirondack region of the USA that this shortage of year-round rentals pushed workers to double or triple up with other workers. This is the case on Bozcaada for the seasonal tourism labourers, who tend to be young and single. However, some civil servants, such as schoolteachers and medical officials who moved to the island with their families, choose to leave the island by asking to be appointed to somewhere else due to the high rents and expenses on the island. This causes a high circulation of civil servants that may affect the stability and the quality of the services provided, commonly criticised during the interviews.

Guimond and Simard (2010) argued that unlike urban gentrification, rural gentrification does not necessarily result in the displacement of local populations, as rural areas tend to give people the opportunity to spread out and around the original settlement. On the other hand, restrictive planning regulations, such as in areas under natural or cultural protection, can act as an agent of gentrification and subsequently result in the lack of affordable housing to the detriment of local populations (Best \& Shucksmith, 2006; Gallent \& Tewdwr-Jones, 2007; Gkartzios \& Scott, 2012). In the case of Bozcaada, the fact that the island as a whole is a conservation area is seen as the main actor in the issue of affordable housing. The strict conservation regulations and the bureaucratic hassles play an important role in the exclusion of lowerincome groups in the local housing market. However, what is intentionally or unintentionally ignored by the local community and administration is the high commercial value of short-term rentals thanks to tourism. Thus, it is argued that tourism is the main agent of indirect displacement or "exclusion of newcomers" on Bozcaada. 


\section{CONCLUSION}

The phenomenon of gentrification as the transformation of an urban neighbourhood through the gradual arrival of middle-class or well-to-do residents, who eventually replace poorer and working-class residents, has been widely accepted as a process that is diverse and varies in outcome (Glass, 1964; Lees, 2000). This made it impossible for researchers to apply fixed criteria and a single definition to gentrification processes around the world (Davidson \& Lees, 2005; Guimond \& Simard, 2010). Therefore, Davidson and Lees (2005) introduced "the core elements of gentrification": the reinvestment of capital; the social upgrading of locales by in-migration of high-income groups; landscape change; and the direct or indirect displacement of low-income groups. Bozcaada has been displaying the core elements of gentrification through the process of rural social change and the structural local economic changes that have been taking place over the last couple of decades (Okumus, 2018).

This paper reports on the changes in the social fabric of Bozcaada with a focus on the demographics, the socio-cultural environment, and the built environment. The emigration of the Rums due to political issues in the 1970s initiated a substantial change in the local community of Bozcaada. The gap in the local population was filled by the in-migration of Turks, who used to work as seasonal agricultural workers on the island. The changes continued with the in-migration of urbanites in the 1990s.

According to the literature, one of the features of the rural gentrification phenomenon is the profile of the in-migrating population, particularly in terms of social class and motivations. The common picture drawn in the Western literature points out the displacement of the lower-income groups by the well-educated higher and middle-income groups with counter-urbanization and rural idyll motivations (Bijker et al., 2012; Cloke et al., 1995; Little, 1987; Phillips, 1993; D P Smith \& Phillips, 2001; Stockdale, 2006; Urry, 1995). However, on Bozcaada there are two distinct groups of newcomers: the first-generation and the secondgeneration newcomers. The first-generation newcomers were mainly middle-class, middle-aged ex-urbanites, who fitted well within the typical profile of rural gentrifiers described in the literature (Cloke et al., 1995; Little, 1987; Phillips, 1993; Urry, 1995). The second-generation newcomers are not wealthier than the long-term residents of the island, who increased their economic status through local tourism development. Besides, they claim that they could move to the island only thanks to the existing properties of their parents, who were firstgeneration newcomers.

The two generations of newcomers also differ from each other with regard to their main motivation for moving to Bozcaada. The firstgeneration consists mainly of middle-aged, affluent ex-urbanites who moved to the island in search of a place to retire to, with the desire of a quiet, peaceful countryside living, as widely pictured in the literature 
"Inherited Gentrification": Changing Profiles of Gentrifiers Via Inheritance, The Case of Bozcaada

(Halfacree, 1993; Hines, 2010; Darren P. Smith, 2002). Although the "escape from urban ills", such as traffic and pollution is the common motivation for both waves of newcomers, the second-generation tends to consist of much younger families whose motivation was also to get away from the stressful working environment typical of cities and start their own business in a more relaxed environment (Bijker et al., 2012; Haartsen \& Stockdale, 2018).

This paper contributes to the rural gentrification literature by introducing the concept of 'inherited gentrification', discussed from a generational perspective. The concept of inherited gentrification represents the transfer of the gentrification phenomenon to a new generation via inheritance. Nonetheless, it does not refer to a simple transfer of ownership of gentrified assets and a reproduction of the process of gentrification by the next generation. It refers to an ongoing and constantly changing process of transformation that, alongside the socio-economic and cultural changes, occurs on the island and in the wider society. Acknowledging this aspect of the process of rural gentrification is of particular importance for the development of policies, strategies, and implementation tools to manage and mitigate the effects of structural transitions in the countryside.

\section{ACKNOWLEDGEMENTS}

This article is originated from the author's PhD thesis "Rethinking Rural Transitions: The Case of Bozcaada, Turkey', supervised by Dr. Suzanne Speak and Dr. Jane Midgley at University of Newcastle.

\section{CONFLICT OF INTEREST}

No conflict of interest was declared by the authors.

\section{FINANCIAL DISCLOSURE}

The authors declared that this study has received no financial support.

\section{ETHICS COMMITTEE APPROVAL}

Ethics committee approval was not required for this article.

\section{LEGAL PUBLIC/PRIVATE PERMISSIONS}

In this research, the necessary permissions were obtained from the relevant participants (individuals, institutions and organizations) during the survey, in-depth interview, focus group interview, observation or experiment.

\section{REFERENCES}

Akgün, A. A., Baycan-Levent, T., Nijkamp, P., \& Poot, J. (2011). Roles of Local and Newcomer Entrepreneurs in Rural Development: A Comparative Meta-analytic Study. Regional Studies, 45(9), 1207-1223. https://doi.org/10.1080/00343401003792500

Argent, N., Tonts, M., \& Stockdale, A. (2014). Rural Migration, Agrarian 
Change, and Institutional Dynamics: Perspectives from the Majority World. Population, Space and Place, 20(4), 299-302. https://doi.org/10.1002/psp.1827

Aydın, Z. (2002). The New Right, Structural Adjustment And Turkish Agriculture, Rural Responses And Survival Strategies. European Journal of Development Research, 14(2), 183-208. https://doi.org/10.1080/714000427

Başaran Uysal, A., \& Sakarya, I. (2018). Rural Gentrification in the North Aegean Countryside (Turkey). ICONARP, International Journal of Architecture \& Planning, 6(1), 99-125. https://doi.org/10.15320

Behar, D., \& İslam, T. (2006). İstanbul'da Soylulastırma: Eski Kentin Yeni Sahipleri. Bilgi University Publications.

Best, P., \& Shucksmith, M. (2006). Homes for Rural Communities: Report of the Joseph Rowntree Foundation Rural Housing Policy Forum. Joseph Rowntree Foundation.

Bijker, R. A., Haartsen, T., \& Strijker, D. (2012). Migration to less-popular rural areas in the Netherlands: Exploring the motivations. Journal of Rural Studies, 28(4), 490-498. https://doi.org/10.1016/j.jrurstud.2012.07.003

Butler, T. (2007). Re-urbanizing London Docklands: Gentrification, suburbanization and new urbanizim? International Journal of Urban and Regional Research, 31(4), 759-781.

Cloke, P. (1983). An Introduction to Rural Settlement Planning. Methuen.

Cloke, P., Phillips, M., \& Thrift, N. (1995). The new middle classes and the social constructs of rural living. In T. Butler \& M. Savage (Eds.). Social Change and the Middle Classes (pp. 220-238). UCL Press.

Darling, E. (2005). The city in the country: Wilderness gentrification and the rent gap. Environment and Plannning A, 37, 1015-1032.

Davidson, M., \& Lees, L. (2005). New-build "gentrification" and London's riverside renaissance. Environment and Planning A, 37(7), 1165-1190. http://www.envplan.com/abstract.cgi?id=a3739

Dinçer, Y., \& Dinçer, İ. (2005). Historical Heritage, Conservation, Restoration in Small Towns and Question of Rural Gentrification in Turkey. ICOMOS 15th General Assembly and Scientific Symposium, 621627.

Enlil, Z. (2000). Yeniden İslevlendirme ve Soylulastırma: Bir Sinıfsal Proje Olarak Eski Kent Merkezlerinin ve Tarihi Konut Dokusunun Yeniden Ele Geçirilmesi. Domus, 8, 46-49.

Ergun, N. (2004). Gentrification in Istanbul. Cities, 21(5), 391-405. https://doi.org/https://doi.org/10.1016/j.cities.2004.07.004

Gallent, N., \& Tewdwr-Jones, M. (2007). Decent Homes For All. Routledge.

Google Maps, (n.d.). [Bozcaada, Turkey].Retrieved December 4, 2020, from https://www.google.com.tr/maps/place/Bozcaada.

Gkartzios, M. (2013). "Leaving Athens": Narratives of counterurbanisation in times of crisis. Journal of Rural Studies, 32, 158167. https://doi.org/10.1016/j.jrurstud.2013.06.003 
"Inherited Gentrification": Changing Profiles of Gentrifiers Via Inheritance, The Case of Bozcaada

Gkartzios, M., \& Scott, M. (2012). Gentrifying the Rural? Planning and Market Processes in Rural Ireland. International Planning Studies, 17(3), 253-276. https://doi.org/10.1080/13563475.2012.696476

Glass, R. (1964). London: Aspects of change. MacGabbon \& Kee.

Guimond, L., \& Simard, M. (2010). Gentrification and neo-rural populations in the Québec countryside: Representations of various actors. Journal of Rural Studies, 26(4), 449-464. https://doi.org/10.1016/j.jrurstud.2010.06.002

Güzey, Ö. (2009). Urban regeneration and increased competitive power: Ankara in an era of globalization. Cities, 26(1), 27-37. https://doi.org/https://doi.org/10.1016/j.cities.2008.11.006

Haartsen, T., \& Stockdale, A. (2018). S/elective belonging: how rural newcomer families with children become stayers. Population, Space and Place, 24(4). https://doi.org/10.1002/psp.2137

Halfacree, K. (1993). Locality and social representation: space, discourse and alternative definitions of the rural. Journal of Rural Studies, 9(1), 2337.

Halfacree, K. (2001). Constructing the object: Taxonomic practices, "counterurbanisation" and positioning marginal rural settlement. International Journal of Population Geography, 7(6), 395-411. https://doi.org/10.1002/ijpg.238

Halfacree, K., \& Boyle, P. (1998). Migration, rurality and the postproductivist countryside. In P. Boyle \& K. Halfacree (Eds.), Migration into rural areas: Theories and issues (pp. 1-20). Wiley.

Hall, P. (2006). Urban exodus hits town and country. Regeneration \& Renewal, 18. http://search.proquest.com/docview/230676159?accountid=12753

Hamnett, C. (2003). Gentrification and the middle-class remaking of inner London, 1961-2001. Urban Studies, 40, 2401-2426.

Hamnett, C. (2009). The new Mikado? Tom Slater, gentrification and displacement. City, 13(4), 476-482. https://doi.org/10.1080/13604810903298672

Higley, R. C. (2008). "Other" Processes of Rural Gentrification and Counter-Urban Migration: Vol. PhD. University of Brighton.

Hines, J. D. (2010). Rural gentrification as permanent tourism: the creation of theNew'West Archipelago as postindustrial cultural space. Environment and Planning D: Society and Space, 28, 509-525.

İslam, T. (2005). Outside the Core: Gentrification in Istanbul. In R. Atkinson \& G. Bridge (Eds.), Gentrification in a Global Context: The New Urban Colonialism. Routledge.

Keyder, C., \& Yenal, Z. (2011). Agrarian Change under Globalization: Markets and Insecurity in Turkish Agriculture. Journal of Agrarian Change, 11(1), 60-86.

Köymen, O., \& Öztürkcan, M. (1999). Türkiye'de Toprak Dağılımı Üstüne Bazı Notlar [Notes on the Land Distribution in Turkey]. In O. Baydar (Ed.), 75 Yılda Köylerden Şehirlere [From Villages to Cities in 75 Years] 
(pp. 75-96). Tarih Vakfi.

Kural, M. S. (2016). Lost (and Gained) in Transition: The Contradictions of Gentrification in Alaçatı, Turkey. Society \& Academia, 70.

Lees, L. (2000). A reappraisal of gentrification: Towards a "geography of gentrification." Progress in Human Geography, 24(3), 389-408.

Ley, D. (1987). Reply: The Rent Gap Revisited. Annals of the Association of American Geographers, 77(3), 465-468. https://doi.org/10.2307/2563280

Little, J. (1987). Rural gentrification and the influence of local level planning. In P. Cloke (Ed.), Rural Planning: Policy into action? (pp. 185199). Harper and Row.

Mitchell, C. J. A. (2004). Making sense of counterurbanization. Journal of Rural Studies, 20(1), 15-34. https://doi.org/10.1016/s07430167(03)00031-7

Murdoch, J., \& Marsden, T. (1994). Reconstituting Rurality: Class, Community and Power in the Development Process. UCL Press.

Okumus, D. (2018). Rethinking Rural Transitions: The Case of Bozcaada, Turkey. Newcastle University.

Phillips, M. (1993). Rural gentrification and the processes of class colonisation. Journal of Rural Studies, 9(2), 123-140. https://doi.org/http://dx.doi.org/10.1016/0743-0167(93)90026-G

Phillips, M. (2002). The Production, Symbolization and Socialization of Gentrification: Impressions from Two Berkshire Villages. Transactions of the Institute of British Geographers, 27(3), 282-308. https://doi.org/10.2307/3804485

Phillips, M. (2005). Differential productions of rural gentrification: Illustrations from North and South Norfolk. Geoforum, 36(4), 477-494. https://doi.org/10.1016/j.geoforum.2004.08.001

Phillips, M. (2009). Gentrification, Rural. International Encyclopedia of Human Geography, 368-375.

Phillips, M., \& Smith, D. P. (2018). Comparative approaches to gentrification: Lessons from the rural. Dialogues in Human Geography, 8(1), 3-25. https://doi.org/10.1177/2043820617752009

Satterlee, S. (2015). Istanbul property: The majestic city wooing foreign investors (12.07.2016). the Telegraph. http://www.telegraph.co.uk/finance/property/expatproperty/12025196/Istanbul-property-the-majestic-city-wooingforeign-investors.html

Scott, M., Smith, D. P., Shucksmith, M., Gallent, N., Halfacree, K., Kilpatrick, S., Johns, S., Vitartas, P., Homisan, M., \& Cherrett, T. (2011). Interface. Planning Theory \& Practice, 12(4), 593-635. https://doi.org/10.1080/14649357.2011.626304

Şen, B. (2011). Kentsel mekânda üçlü ittifak: sanayisizleşme, soylulaştırma, yeni orta sınıf. İÜ Siyasal Bilgiler Fakültesi Dergisi, 44, 121.

Shucksmith, M. (2012). Class, Power and Inequality in Rural Areas: 
"Inherited Gentrification": Changing Profiles of Gentrifiers Via Inheritance, The Case of Bozcaada

Beyond Social Exclusion? Sociologia Ruralis, 52(4), 377-397. https://doi.org/10.1111/j.1467-9523.2012.00570.x

Skeggs, B. (2004). Class, Self, Culture. Routledge.

Smith, D P, \& Phillips, D. A. (2001). Socio-cultural representations of greentrified Pennine rurality. Journal of Rural Studies, 17(4), 457-469. https://doi.org/http://dx.doi.org/10.1016/S0743-0167(01)00014-6

Smith, Darren P. (2002). Rural gatekeepers and 'greentrified' pennine rurality: Opening and closing the access gates? Social \& Cultural Geography, $3(4)$, 447-463. https://doi.org/10.1080/14649365.2002.9709634

Smith, N. (1979). Gentrification and capital: practice and ideology in Society Hill. Antipode, 11, 24-35.

Stockdale, A. (2006). The role of a "retirement transition" in the repopulation of rural areas. Population, Space and Place, 12(1), 1-13. https://doi.org/10.1002/psp.380

Stockdale, A. (2010). The diverse geographies of rural gentrification in Scotland. Journal of Rural Studies, 26(1), 31-40. https://doi.org/10.1016/j.jrurstud.2009.04.001

Stockdale, A., Findlay, A., \& Short, D. (2000). The repopulation of rural Scotland: opportunity and threat. Journal of Rural Studies, 16(2), 243257. 0167(99)00045-5 https://doi.org/http://dx.doi.org/10.1016/S0743-

Sutherland, L. A. (2012). Return of the gentleman farmer?: Conceptualising gentrification in UK agriculture. Journal of Rural Studies, 28(4), 568-576. https://doi.org/10.1016/j.jrurstud.2012.05.001

Tekeli, I. (2008). Türkiye'de Bölgesel Eşitsizlik Ve Bölge Planlama Yazıları [Articles on Regional Disparities and Planning in Turkey] (Vol. 2). Tarih Vakfi.

Tezcan, A. M. (2010). Rethinking Transformation with Tourism: The Case of İzmir-Alaçatı [Middle East Technical University]. https://doi.org/10.1558/jsrnc.v4il.24

TUIK. (2015). Databases (01.08.2015). Turkish Statistical Institute. http://www.turkstat.gov.tr/

Urry, J. (1995). A middle-class countryside. In T. Butler (Ed.), Social Change and the Middle Classes (pp. 205-219). UCL Press.

Uzun, C. N. (2003). The impact of urban renewal and gentrification on urban fabric: three cases in Turkey. Tijdschrift Voor Economische En Sociale Geografie, 94(3), 363-375. https://doi.org/10.1111/14679663.00263

Woods, M. (2005). Rural Geography: Processes, Responses and Experiences in Rural Restructuring. SAGE.

Zukin, S. (1990). Socio-Spatial Prototypes of a New Organization of Consumption: The Role of Real Cultural Capital. Sociology, 24(1), 37-56. https://doi.org/10.1177/0038038590024001005 


\section{Duygu Okumuş}

\section{Resume}

Duygu Okumuş currently works as a lecturer in Department of City and Regional Planning at Bursa Technical University. She received her MSc. and PhD. in planning from University of Newcastle, UK. Her research interest includes socioeconomic and cultural transitions in rural areas, particularly gentrification processes. 